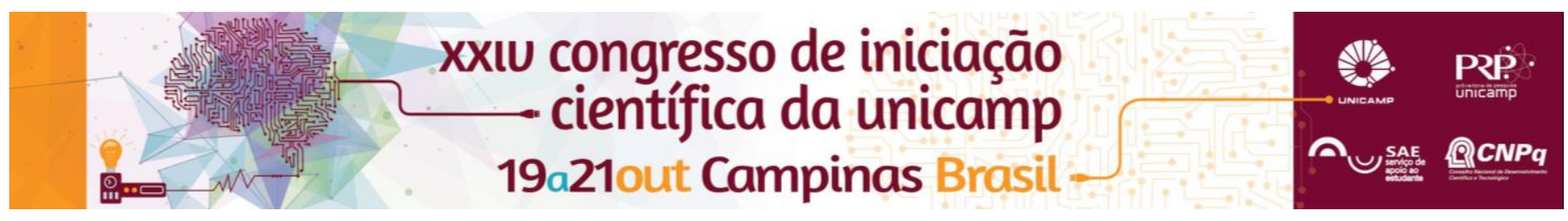

\title{
Desenvolvimento de um Robô para Análise de Acessibilidade em Ambientes
}

\author{
Allan Thales Amaral de Pontes*, Talía Simões dos Santos.
}

\section{Resumo}

Este projeto trata da construção de um robô, com as dimensões aproximadas de uma cadeira de rodas para analisar as condições de acessibilidade em ambientes diversos. A ideia principal é fazer com que exista ciência sobre o esforço e quantidade de calorias que são gastas, para que um cadeirante possa percorrer um determinado caminho. Para isso, o robô cadeira é controlado remotamente, por meio de uma comunicação Wi-Fi.

\section{Palavras-chave:}

Acessibilidade, Cadeira de rodas, Robô.

\section{Introdução}

Qual o esforço necessário para que um cadeirante chegue ao seu destino, utilizando pontos de acesso e rampas? A investigação do caminho a ser percorrido por um cadeirante é de extrema importância para definir a viabilidade do acesso. Neste projeto foi desenvolvido um robô para analisar as condições de acessibilidade em ambientes diversos.

O robô tem por desafio registrar graus de inclinação e esforço empregados na locomoção, além do desenvolvimento de uma interface cérebro - computador, para que o robô possa se locomover e ser controlado remotamente, podendo com isso, realizar os cálculos e experimentos necessários na tarefa. Para que isso seja possível, é relacionada a caloria média gasta por um cadeirante comum com a inclinação e distância percorrida pelo robô. Posteriormente é feita uma equivalência aproximada.

\section{Resultados e Discussão}

O robô apresentado na Fig. 1 (A) foi testado e controlado via web. O robô apresentou algumas folgas decorrentes da polia, porém, o problema não atrapalhou o controle do mesmo (Fig. 1 (B)) para realizar a análise de inclinação de rampas de acesso. Os dados coletados através dos sensores, tais como, distância percorrida e inclinação do robô estão sendo analisados, conforme Fig. 2.

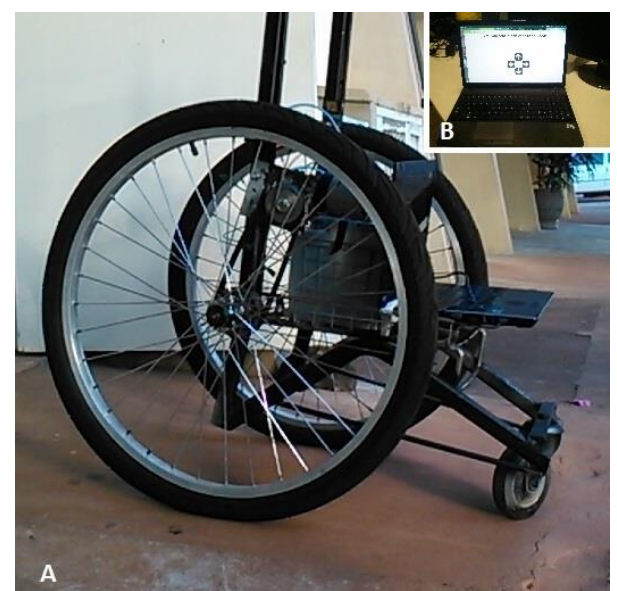

Figura 1. A) Robô subindo a rampa de acesso; B) Controle web do robô.

Uma relação com os valores de esforço obtido, experimentalmente, com um cadeirante, permitiu realizar uma relação em diferentes condições. Com esses dados conhecidos, é possível que o robô realize uma análise em tempo real do esforço de um cadeirante, em quaisquer condições de inclinação. Outro problema encontrado foi a alimentação do computador, realizada por uma bateria automotiva, pois todo o sistema alimentado pela mesma fonte acabou gerando ruído decorrente do tipo de motor utilizado. Então, foi feita uma alimentação isolada para a unidade computacional embarcada e o circuito eletrônico de potência.

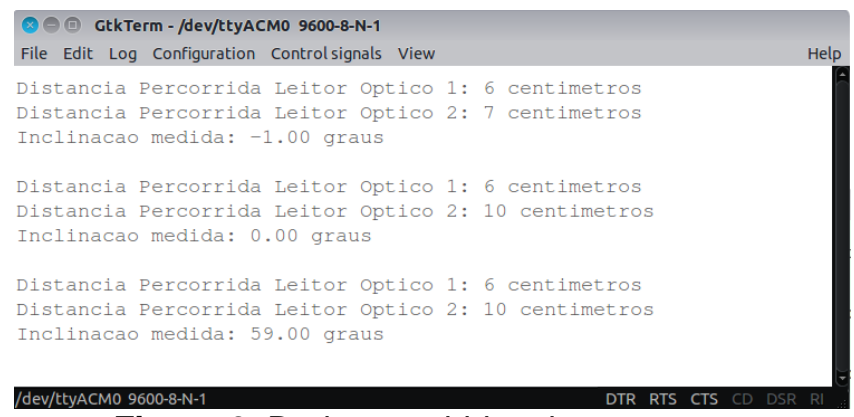

Figura 2. Dados recebidos dos sensores.

\section{Conclusões}

Variações na distância percorrida e na inclinação da cadeira de rodas causam um imenso impacto no esforço empregado pelo cadeirante. O controle do robô por meio de comunicação web auxilia na precisão dos valores medidos, uma vez que não há interferência externa na cadeira de rodas. O armazenamento e posterior estudo dos dados obtidos demonstram que o robô auxilia na análise de determinadas rampas de acesso, assim como em determinados trajetos de cadeirantes.

\section{Agradecimentos}

Ao Eng. Rodrigo Luiz Ximenes e Prof. Paulo do Cotil pelo suporte técnico para realização deste trabalho.

\footnotetext{
${ }^{1}$ Kim, J.; Brienza, D. M.; Lynch, R. D.; Cooper, R. A.; Boninger, M. L. (2008). Effectiveness Evaluation of a Remote Accessibility Assessment System for Wheelchair Users Using Virtualized Reality. Archives of Physical Medicine and Rehabilitation, v.89, no3, pp 470-479.

${ }^{2}$ Kim, C. S.; Lee, D.; Kwon, S.; Chung, M. K. (2014). Effects of ramp slope, ramp height and users' pushing force on performance, muscular activity and subjective ratings during wheelchair driving on a ramp. International Journal of Industrial Ergonomics, v.44, no5, pp 636-646.

${ }^{3}$ Pruski, A. (2010). A unified approach to accessibility for a person in a wheelchair. Robotics and Autonomous Systems, v.58, no11, pp 1177-1184
} 